\title{
OPTIMASI MASSA RANGKA KENDARAAN ELEKTRIK PENGANGKUT SAMPAH DENGAN SIMULASI METODE ELEMEN HINGGA
}

\author{
Roby $^{1)}$, Didi Widya Utama ${ }^{1)}$ dan Noor Eddy ${ }^{2)}$ \\ ${ }^{1)}$ Program Studi Teknik Mesin, Fakultas Teknik Univesitas Tarumanagara, Jakarta \\ 2) Jurusan Teknik Mesin, FTI Universitas Trisakti Jakarta \\ e-mail: 2008roby@gmail.com¹,didi_wu@hotmail.com²,noor@trisakti.ac.id ${ }^{3}$
}

\begin{abstract}
Residential waste contributes up to 55\% of the total volume of urban waste such as in Jakarta. It makes the transport process of residential waste to temprorary landfill site (TPS) that has been existed, less efficient. Transporting waste process with garbage cart is depended on the manpower, while with the garbage truck, the vehicle's width and the use of fossil fuels are the weaknesses. Thus, the design concept of a waste transport vehicle using electric motor as driving source is made which has the same payload capacity as a garbage cart in general. Garbage payload along with the main components must be strongly supported by the vehicle frame, which incidentally serves as the support vehicle. In this study, discussed the optimization of electric waste transport vehicle with the help of 3-dimensional CAD modelling, then simulated with static loading to obtain the results of the stress, displacement with the maximum value and location, and can assign the payload distribution position. With variable of the beam profile shape and its thickness, then obtained the optimal order forms, which frame weighs as light as possible but still robust in supporting given loads, which is frame with a cylindrical hollow profile with diameter of $60.3 \mathrm{~mm}$ and thickness of $4 \mathrm{~mm}$.
\end{abstract}

Keyword: waste transport electric vehicle, chassis frame, stress analysis, mass, strength, stiffness

\section{PENDAHULUAN}

Sampah adalah salah satu masalah utama pada perkotaan besar seperti Jakarta. Volume sampah yang dihasilkan dapat mencapai angka 7.500 ton/hari, dengan 55\% dari total volume sampah tersebut disumbangkan oleh sampah perumahan [1]. Sampah perumahan yang sedemikian banyaknya dan harus ditransportasikan menuju Tempat Pembuangan Sementara (TPS) menjadikan proses transportasi sampah yang telah ada saat ini, yakni dengan gerobak sampah yang ditarik oleh tenaga manusia dan truk sampah, menjadi kurang efisien. Gerobak sampah yang ditarik tenaga manusia sangat bergantung pada kekuatan penarik, sementara dengan truk sampah, terdapat kelemahan yaitu akses jalan perumahan yang sulit dan adanya pemborosan bahan bakar fosil mengingat bahwa kendaraan dinyalakan terus saat menunggu pekerja memasukkan sampah ke dalam bak. Maka dari itu, guna mengatasi kelemahan tersebut, dibuat sebuah konsep perancangan kendaraan pengangkut sampah yang menggunakan motor listrik dan baterai sebagai sumber penggeraknya. Kendaraan elektrik pengangkut sampah yang dibuat ini direncanakan memiliki kapasitas angkut yang sama seperti pada gerobak sampah, sehingga perlu dipastikan bahwa rangka kendaraan elektrik ini dapat kuat, dan tidak terjadi kegagalan ketika dioperasikan.

Rangka merupakan bagian yang penting karena berfungsi sebagai tempat tumpuan body dan beban-beban dari komponen lain pada kendaraan [2]. Rangka perlu dipastikan dapat menahan beban yang umumnya adalah beban statis dan dapat memberi dukungan pada berbagai komponen kendaraan [3,4]. Guna mencegah kegagalan terjadi pada rangka sebelum dimanufaktur, stress analysis berbasis metode elemen hingga dilakukan, sehingga diketahui besar serta posisi stress dan defleksi maksimum yang dapat digunakan sebagai kriteria perancangan [5] [6]. Dari hasil tersebut, dapat dilakukan perbaikan dan modifikasi untuk pengurangan massa rangka [7].

\section{METODE PENELITIAN}

Secara umum, metode penelitian yang dilakukan ditunjukkan seperti diagram alir pada Gambar 1 di bawah.

Hasil pemodelan kendaraan elektrik pengangkut sampah beserta bentuk rangka yang digunakan seperti pada Gambar 2. Dari pemodelan 3 dimensi konsep rancangan awal, kemudian dilakukan simulasi. Dengan konsep awal rancangan rangka, kemudian dilakukan optimasi dengan menggunakan ukuran ketebalan dan bentuk profil batang yang berbeda. Hal ini disebabkan bahwa 
bentuk profil yang berbeda akan memberikan pengaruh terhadap tegangan serta defleksi yang dialami rangka [8].

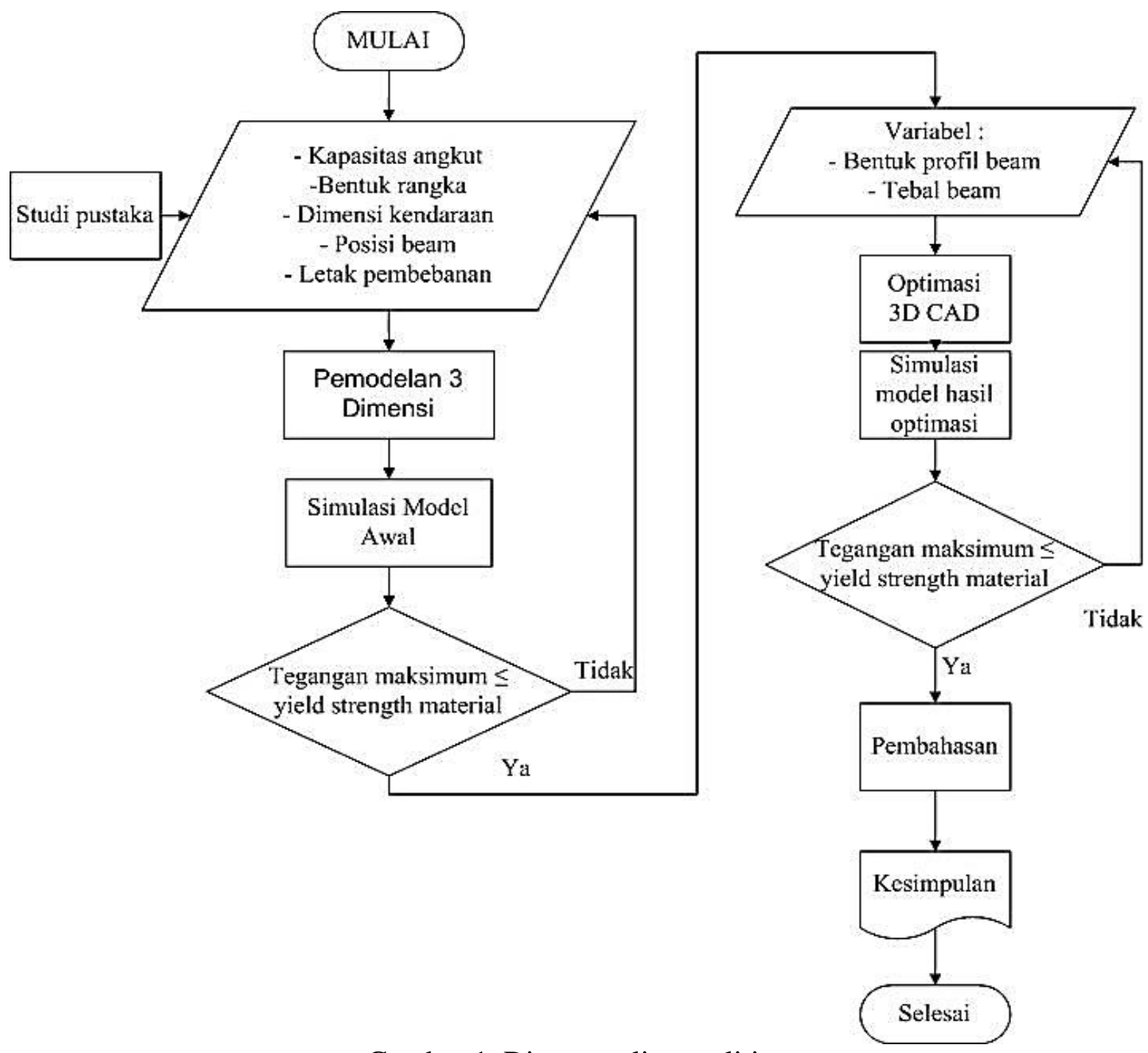

Gambar 1. Diagram alir penelitian

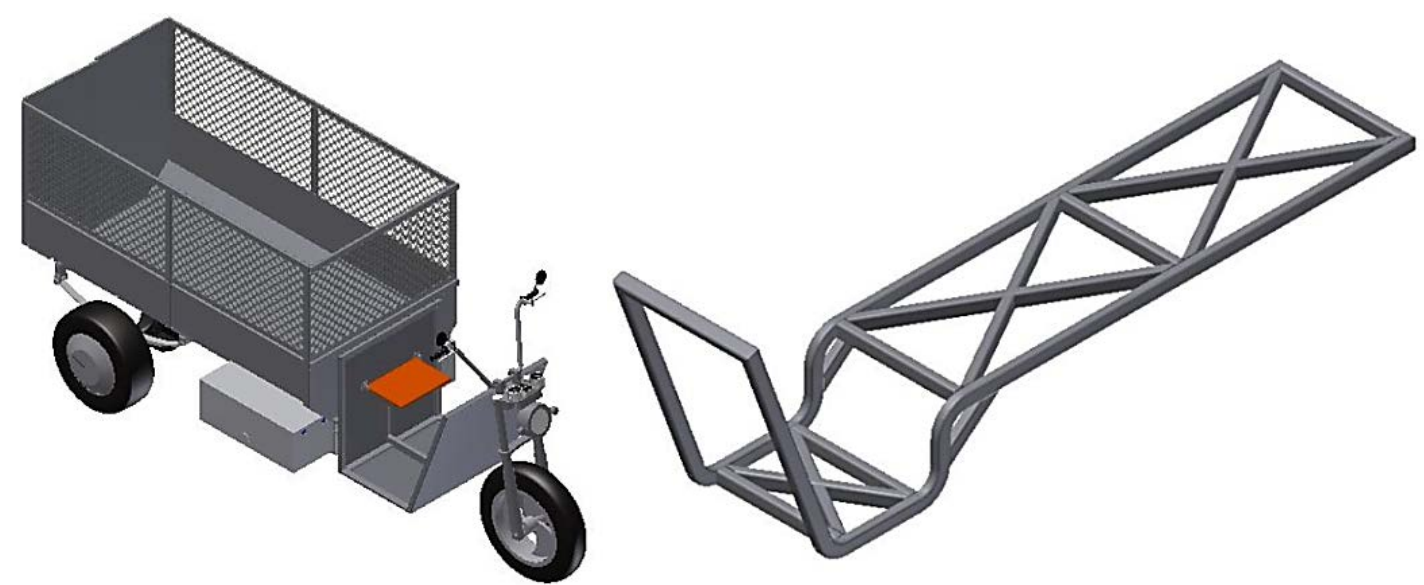

Gambar 2. Pemodelan 3 dimensi kendaraan elektrik pengangkut sampah

Untuk posisi pembebanan dan batasan pada kendaraan, ditunjukkan pada Gambar 3 di bawah. 


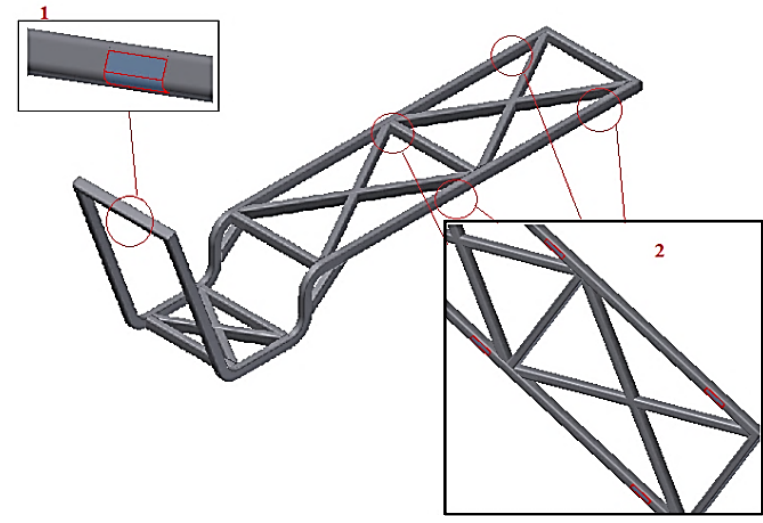

(a)

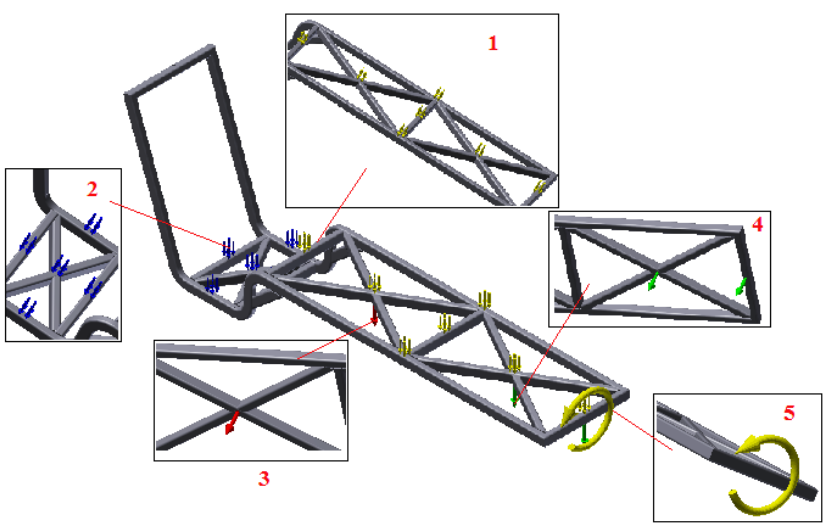

(b)

Gambar 1. Posisi batasan pada kendaraan (a), dan beban statis pada kendaraan (b)

Gambar 3 (a) menunjukkan posisi batasan(constraint), di mana pada posisi tersebut adalah tempat pemasangan tiang kemudi dan pegas daun pada kendaraan. Sementara gambar 3 (b), adalah detail pembebanan, yang terdiri dari beban angkut sampah sebesar $500 \mathrm{~kg}$ (Gambar 3b sub 1), pengemudi sebesar $100 \mathrm{~kg}$ (Gambar 3b sub 2), motor listrik (Gambar 3b sub 3), baterai (Gambar 3b sub 4) dan beban torsi yang diperoleh dari reaksi tumpuan rangka dikalikan dengan jarak track kendaraan [9] (Gambar 3b sub 5). Untuk material yang digunakan adalah material mild steel yang memiliki yield stress 206,98 MPa.

\section{HASIL DAN PEMBAHASAN}

a. Rangka awal

Hasil simulasi rancangan rangka awal yaitu mengalami von mises stress maksimum sebesar 80,74 MPa yang berada pada lokasi tumpuan belakang rangka. Sementara defleksi maksimum adalah $0,163 \mathrm{~mm}$ pada bagian tengah rangka. Hasil perhitungan untuk torsional stiffness menunjukkan angka sebesar $127.600 \mathrm{Nm} /$ deg. Dengan demikian konsep rancangan awal rangka dinyatakan aman karena mengalami tegangan di bawah nilai yield strength material, dengan safety factor 2,56, di mana angka ini masih berada di atas safety factor yang aman yaitu1,5, dan kekakuan terhadap torsi di atas rata-rata, yaitu sekitar $10.000 \mathrm{Nm} / \mathrm{deg}$ [10].

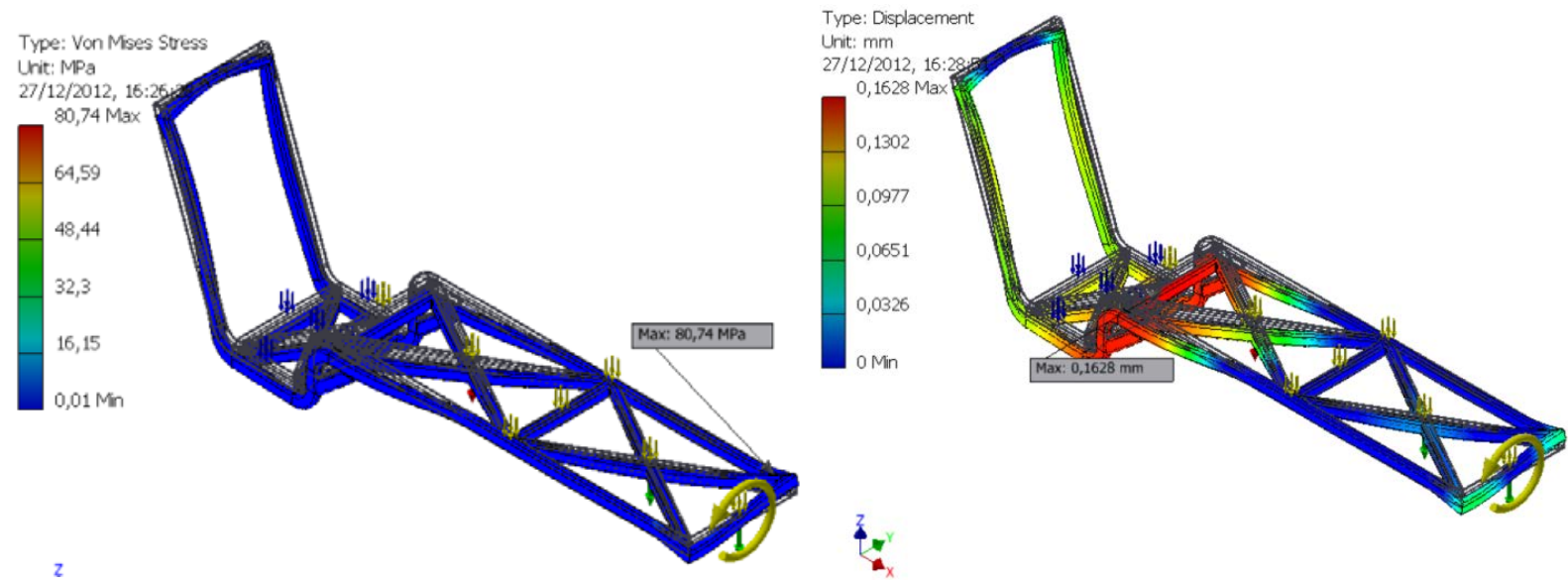

Gambar 2 Von mises stress dan defleksi maksimum pada rancangan rangka awal.

Rangka pada rancangan awal ini memiliki massa sebesar 107,71 kg. Massa rangka pada konsep rancangan awal ini akan dioptimasi untuk didapatkan yang paling ringan. Bentuk optimasi terhadap rancangan awal rangka adalah seperti pada tabel di bawah. 
Tabel 1. Modifikasi yang dilakukan terhadap rangka awal

\begin{tabular}{c|c|c}
\hline No & Jenis batang & Ukuran (mm) \\
\hline 1 & Rectangular hollow & $60 \times 40 \times 4$ \\
2 & Square hollow & $60 \times 60 \times 5$ \\
3 & Square hollow & $60 \times 60 \times 4$ \\
4 & Cylindrical hollow & $60,3 \times 5$ \\
5 & Cylindrical hollow & $60,3 \times 4$ \\
\hline
\end{tabular}

b. Rangka optimasi 1

Untuk rangka optimasi 1, yaitu rangka yang menggunakan rectangular hollow berukuran 60x40x4 mm, hasilnya ditunjukkan pada Gambar 5.

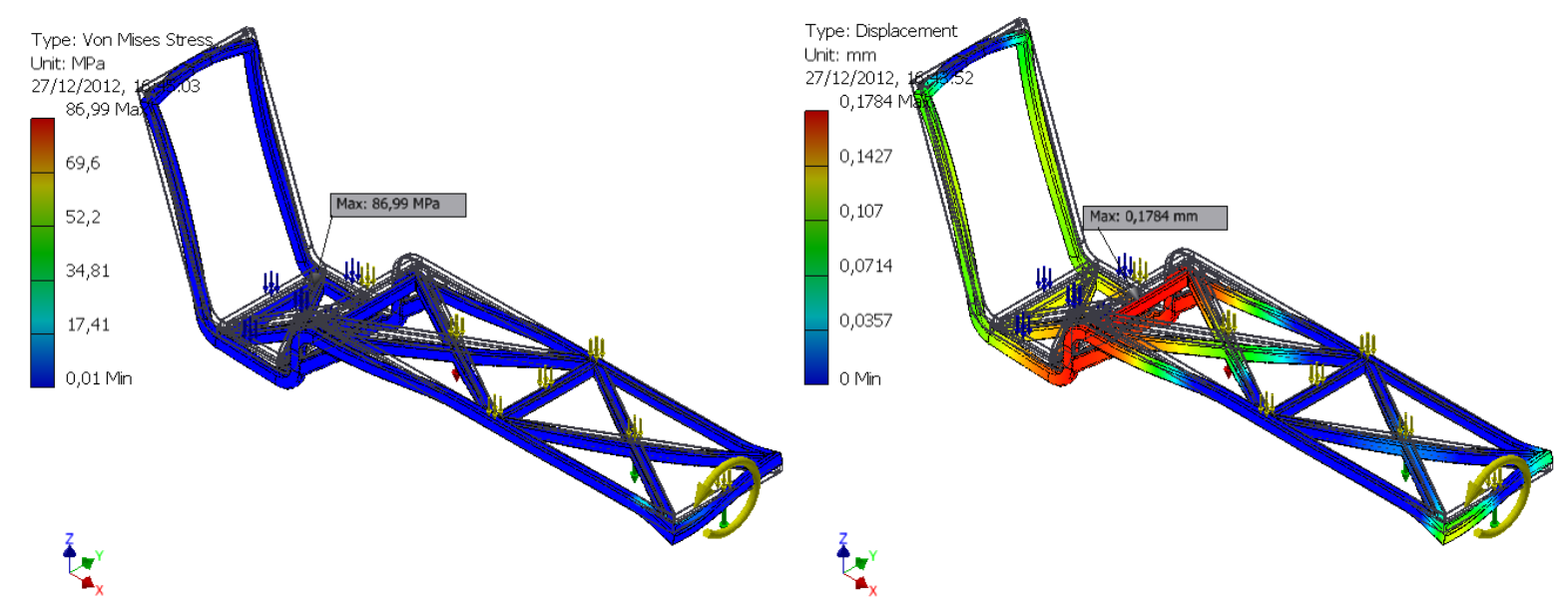

Gambar 3. Von mises stress dan defleksi rangka optimasi 1

Tegangan maksimum yang dialami rangka optimasi 1 meningkat menjadi 86,99 MPa dengan defleksi maksimum sebesar 0,178 mm. Berdasarkan hasil tegangan, maka diketahui bahwa rangka adalah aman dengan safety factor sebesar 2,38 dan torsional stiffness sebesar 112.411,76 $\mathrm{Nm} /$ deg. Massa rangka optimasi 1 yaitu 89,52 kg. Terdapat pengurangan massa yang cukup signifikan dibanding dengan pengubahan ketebalan batang menjadi $4 \mathrm{~mm}$.

\section{c. Rangka optimasi 2}

Rangka optimasi 2 menggunakan bentuk batang square hollow dengan ukuran 60x60x5 mm. Hasil von mises stress dan defleksi ditunjukkan pada Gambar 6.

Rangka optimasi 2 mengalami tegangan maksimum 73,44 MPa yang berarti rangka aman dengan safety factor sebesar 2,82. Dengan defleksi maksimum sebesar 0,097 mm, dihasilkan kekakuan torsi sebesar 217.066,67 Nm/deg, sehingga dapat dikatakan bahwa rangka optimasi 2 sangat kaku. Massa rangka optimasi 2 yaitu sebesar 128,5 kg.

\section{d. Rangka optimasi 3}

Rangka optimasi 3 menggunakan batang square hollow yang berukuran sama seperti pada rangka optimasi 2, hanya saja diubah ketebalannya menjadi $4 \mathrm{~mm}$, guna diperoleh massa rangka yang lebih ringan. Hasil von mises stress dan defleksi ditunjukkan pada Gambar 7.

Tegangan von mises stress maksimum terjadi pada daerah tumpuan belakang rangka, dengan nilai maksimum 97,52 MPa. Dengan tegangan maksimum 97,52 MPa, maka safety factor rangka adalah 2,12. Defleksi maksimum terjadi pada daerah tengah rangka sebesar $0,128 \mathrm{~mm}$. Hasil defleksi maksimum ini digunakan dalam perhitungan untuk mengetahui kekakuan terhadap torsi dan diperoleh hasil perhitungan kekakuan torsi adalah 163.950Nm/deg. Dengan hasil tersebut, maka 
rangka optimasi 3 ini telah memenuhi tolak ukur kekuatan dan kekakuan rangka. Massa rangka optimasi 3 adalah 105,87 kg.

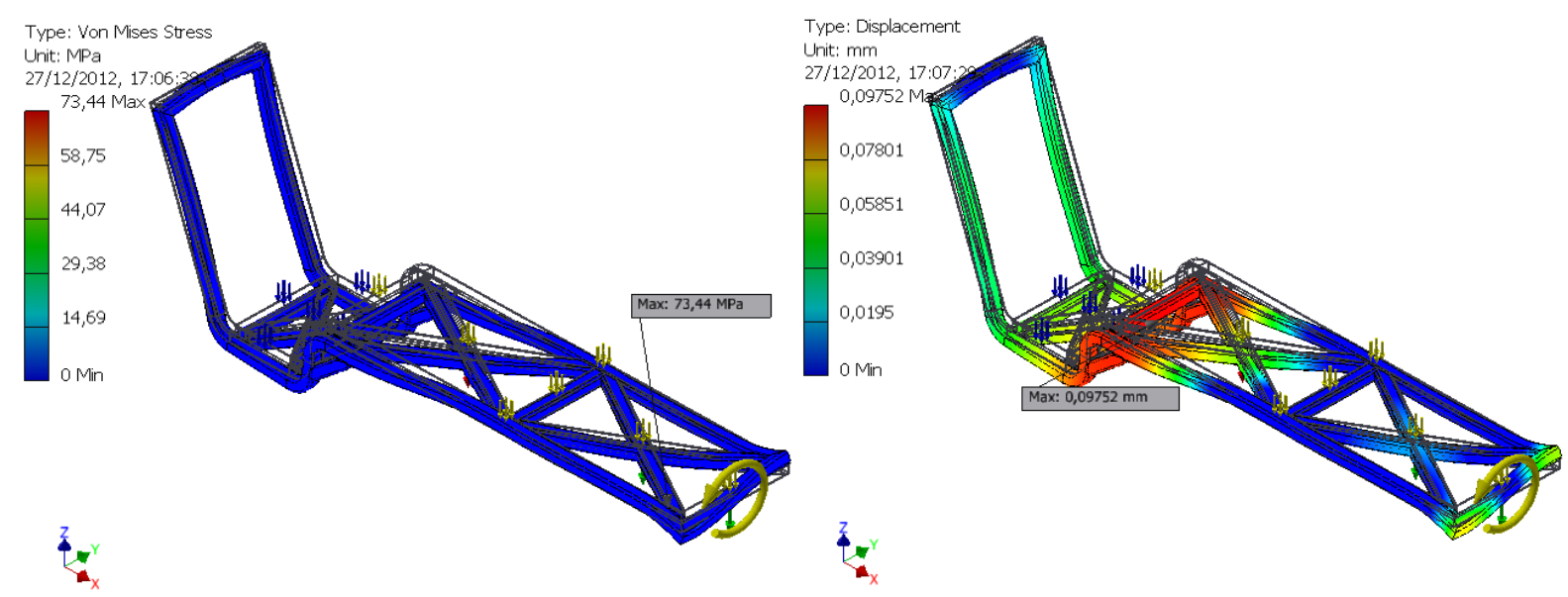

Gambar 4. Von mises stress dan defleksi pada rangka optimasi 2

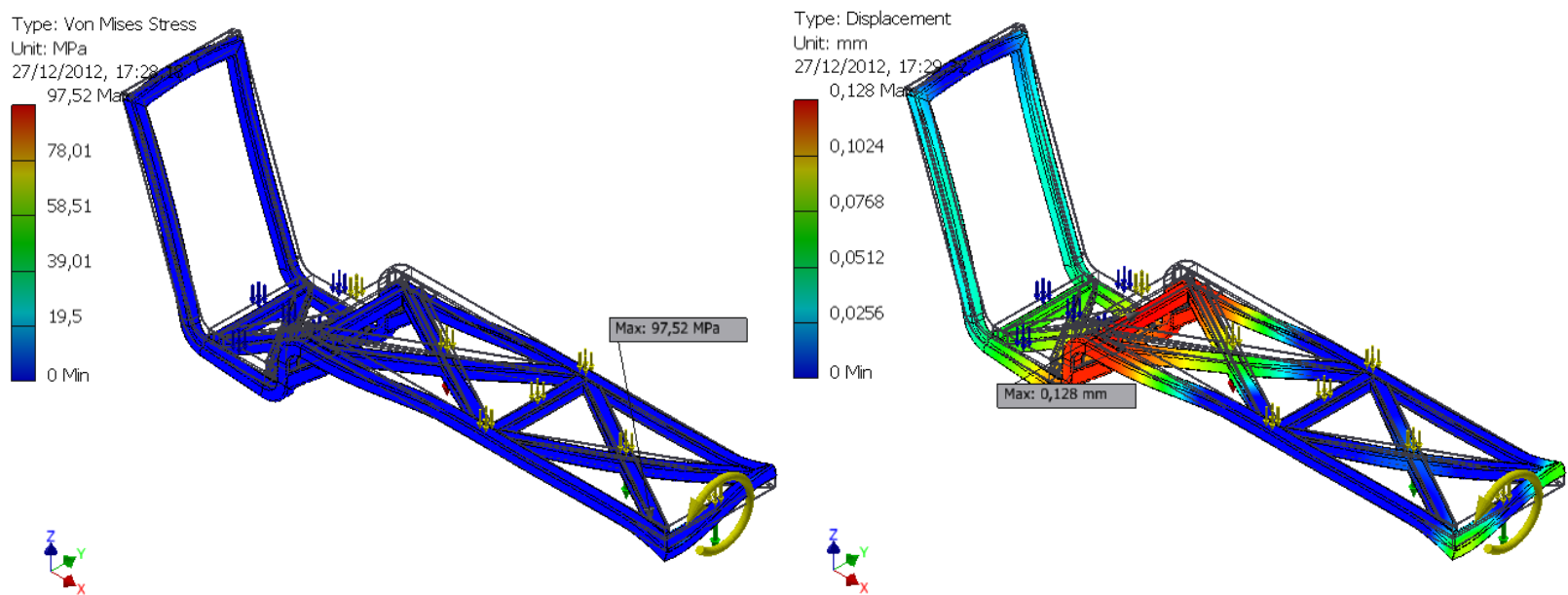

Gambar 5. Von mises stress dan defleksi maksimum rangka optimasi 3

\section{e. Rangka optimasi 4}

Setelah meninjau dua jenis profil batang yang digunakan, dicoba untuk menggunakan batang berprofil cylindrical hollow dengan ukuran mendekati ukuran penampang batang pada rangka awal, yaitu berdiameter 60,3 mm dengan ketebalan yang sama pada rangka awal. Diperoleh hasil von mises stress sebesar 40,9 MPa dan defleksi sebesar 0,21 mm.

Tegangan yang dialami rangka berprofil cylindrical hollow ini memiliki besar nilai yang jauh lebih kecil dibanding dengan konsep rancangan rangka yang lain. Rangka optimasi 4 ini memiliki nilai safety factor yang paling besar, yaitu 5,06. Bila defleksi ditinjau, maka kekakuan terhadap torsi yang dimiliki rangka optimasi 4 adalah $96.200 \mathrm{Nm} / \mathrm{deg}$. Rangka optimasi 4 yang memiliki massa sebesar 108,9 kg dapat dilihat pada Gambar 8.

\section{f. Rangka optimasi 5}

Setelah diperoleh hasil tegangan maksimum yang paling rendah, dengan kekakuan torsi yang baik, maka dicoba untuk menggunakan ketebalan $4 \mathrm{~mm}$ pada rangka berprofil cylindrical hollow, dengan harapan diperoleh rangka yang memiliki tegangan yang paling baik dan tetap kaku, dan memiliki massa yang paling ringan. Hasil yang diperoleh yaitu seperti pada Gambar 9.

Von mises stress terbesar adalah sebesar 69,81 MPa, di mana nilai tegangan maksimum ini tetap lebih kecil bila dibanding rangka yang menggunakan batang rectangular maupun square hollow. Selain itu, defleksi maksimum rangka ini adalah sebesar 0,24 mm, yang berarti kekakuan 
rangka terhadap torsi adalah sebesar 80.791,3 Nm/deg. Upaya pengurangan massa yang dilakukan menghasilkan massa rangka optimasi 5 sebesar 89,45 kg.

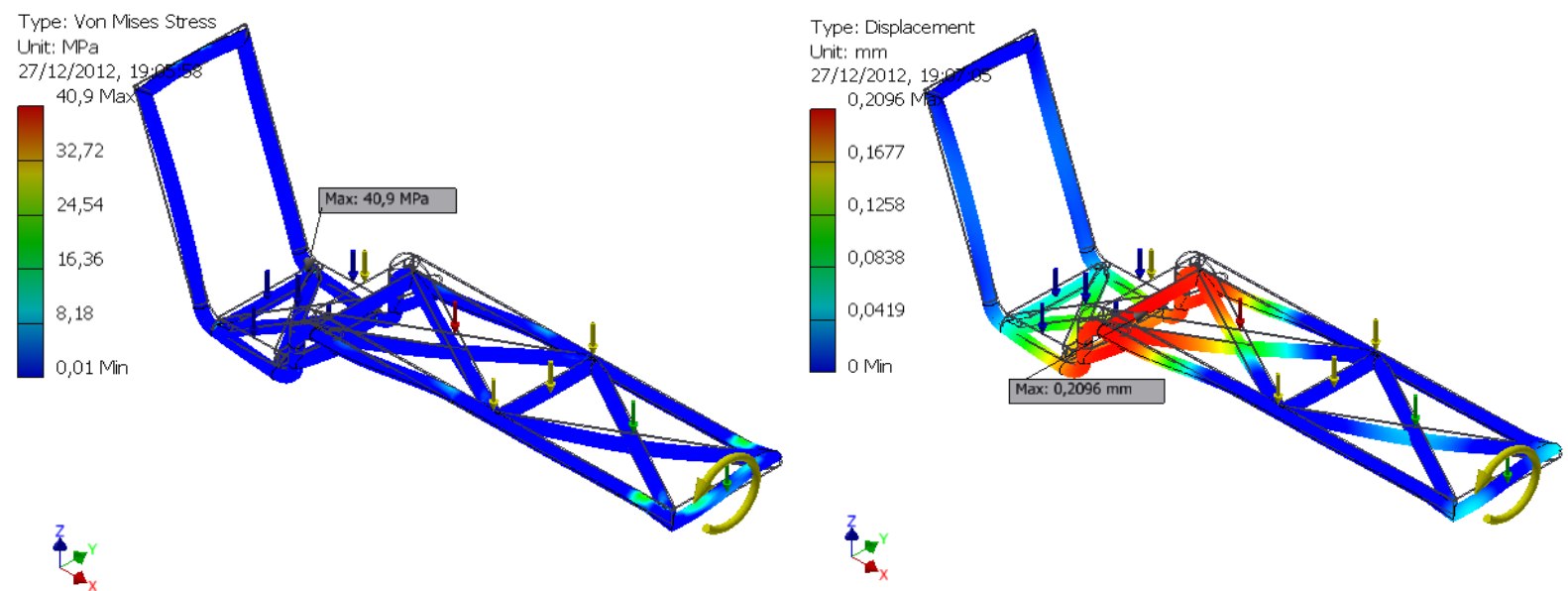

Gambar 6. Von mises stress dan defleksi maksimum rangka optimasi 4

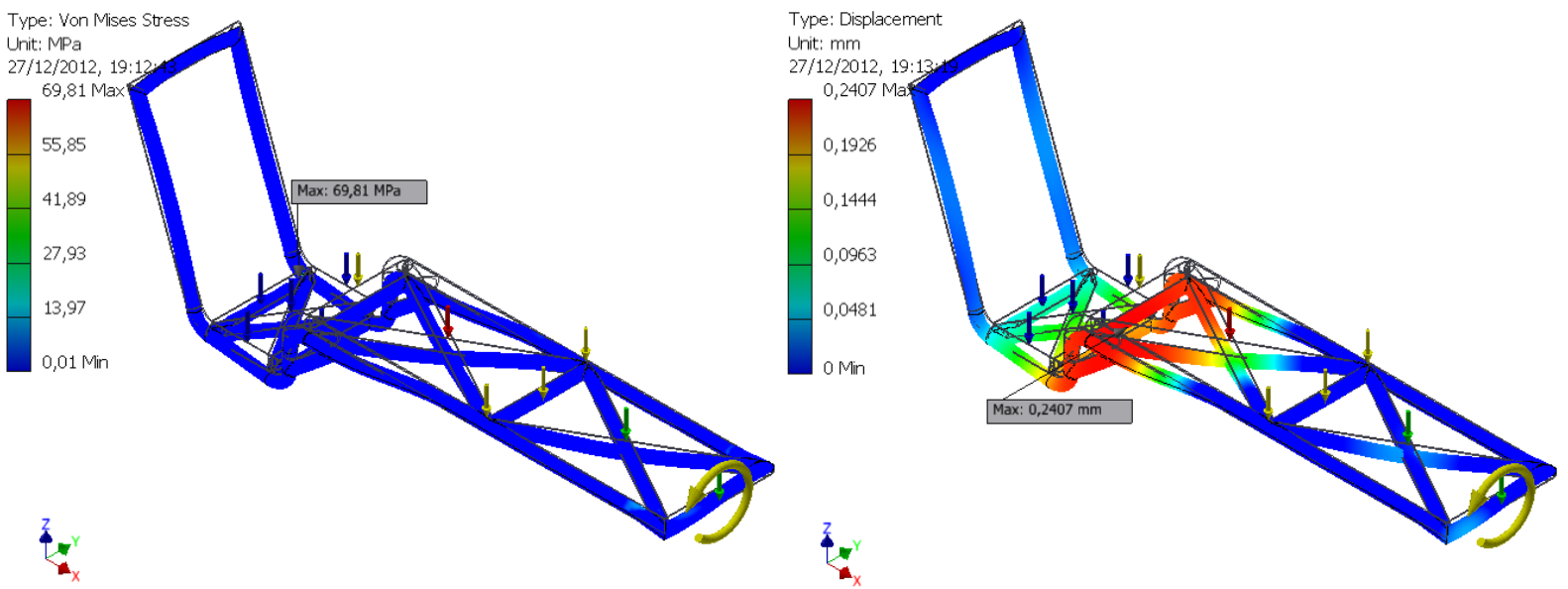

Gambar 7. Von mises stress dan defleksi rangka optimasi 5

\section{g. Pemilihan rangka optimal}

Secara umum, hasil dari simulasi keseluruhan konsep rancangan rangka adalah seperti ditunjukkan pada Tabel 2.

Terlihat bahwa rangka yang memiliki massa paling ringan adalah rangka optimasi 1 yang berprofil rectangular hollow dan rangka optimasi 5 yang berprofil cylindrical hollow. Akan tetapi melihat dari besarnya tegangan maksimum serta kekakuan torsi yang masih di atas rata-rata kendaraan pada umumnya, maka rangka yang paling optimal adalah rangka optimasi 5, yang menggunakan batang cylindrical hollow dengan ukuran diameter 60,3 x $4 \mathrm{~mm}$. Untuk grafik hasil simulasi seluruh konsep rangka yang dibuat, dapat terlihat pada Gambar 10.

Tabel 2. Hasil simulasi keseluruhan konsep rancangan rangka

\begin{tabular}{cccccc}
\hline No. & Bentuk profil & Ukuran $(\mathrm{mm})$ & Von mises stress $(\mathrm{MPa})$ & Defleksi $(\mathrm{mm})$ & Massa $(\mathrm{kg})$ \\
\hline 1 & Rectangular & $60 \times 40 \times 5$ & 80,74 & 0,163 & 107,71 \\
2 & Rectangular & $60 \times 40 \times 4$ & 86,99 & 0,178 & 89,53 \\
3 & Square & $60 \times 60 \times 5$ & 73,44 & 0,097 & 128,5 \\
4 & Square & $60 \times 60 \times 4$ & 97,52 & 0,128 & 105,87 \\
5 & Cylindrical & $60,3 \times 5$ & 40,9 & 0,21 & 108,9 \\
6 & Cylindrical & $60,3 \times 4$ & 69,81 & 0,24 & 89,45 \\
\hline
\end{tabular}




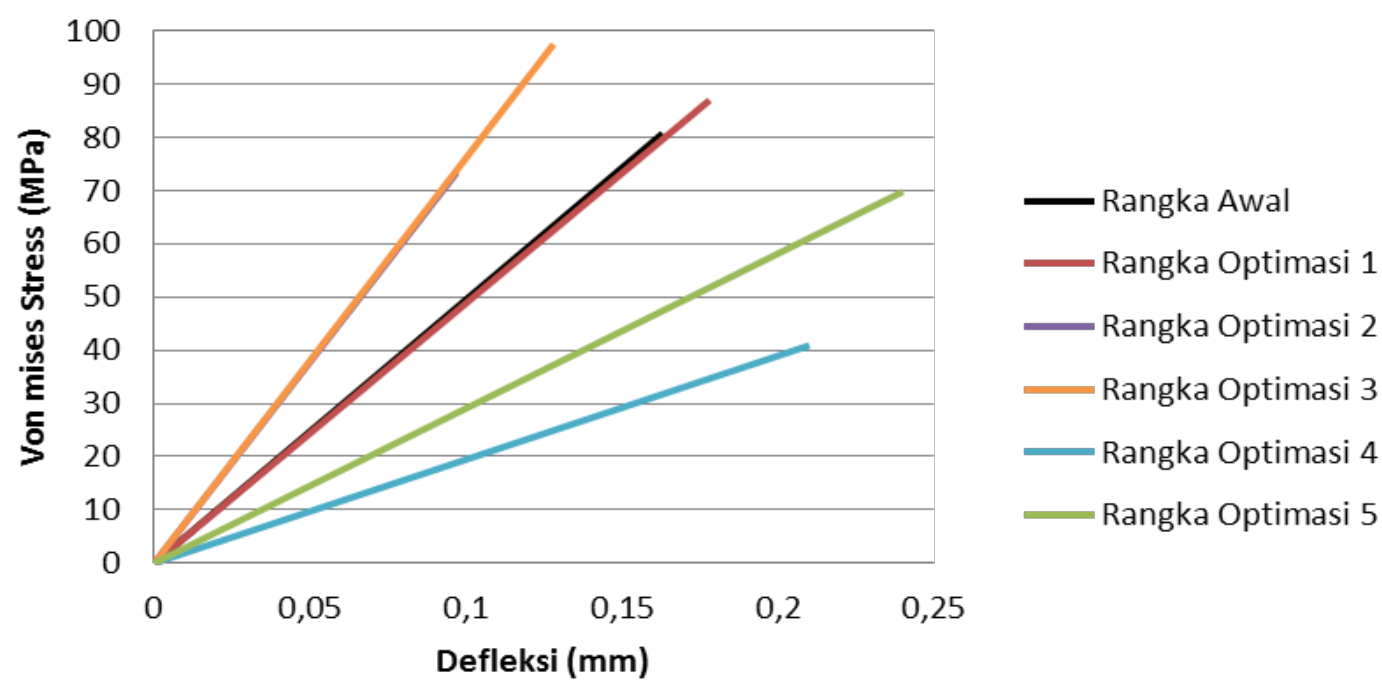

Gambar 8. Hasil simulasi seluruh konsep rangka

\section{KESIMPULAN}

Berdasarkan pengamatan, analisis serta simulasi yang telah dilakukan pada berbagai konsep rancangan rangka, dapat diambil kesimpulan bahwa semua konsep perancangan rangka yang menggunakan berbagai bentuk serta ukuran ketebalan batang adalah aman dengan pembebanan statis. Di antara sekian banyak konsep rancangan rangka yang telah dibuat dan ditinjau secara keilmuan, maka rangka yang paling optimal, dalam artian rangka paling ringan namun kokoh adalah rangka optimasi 5 yang menggunakan batang cylindrical hollow berukuran diameter 60,3 mm dengan ketebalan batang $4 \mathrm{~mm}$. Rangka optimasi 5 ini memiliki massa 89,45 $\mathrm{kg}$, dan mengalami von mises stress sebesar 80,74 MPa, dengan safety factor sebesar 2,97 dan memiliki besar nilai kekakuan melebihi kekakuan kendaraan pada umumnya yaitu sebesar 80.791,3 Nm/deg.

Bila ditinjau dari segi kemudahan untuk dimanufaktur, maka rangka yang lebih optimal adalah rangka optimasi 1 , yaitu rangka yang menggunakan batang rectangular hollow berukuran 60x40x4 (mm). Rangka optimasi 1 mengalami von mises stress sebesar 86,99 MPa dan memiliki kekakuan di atas kekakuan kendaraan pada umumnya, sehingga dapat dikatakan bahwa konsep rangka ini memiliki kekuatan serta kekakuan yang baik.

\section{DAFTAR PUSTAKA}

[1] Indonesia Infrastructure Initiative (2012) Sampah Harus Digarap dari Hulu ke Hilir. [Online]. http://www.indii.co.id/upload_file/201205102118380.Sampah\%20Harus\%20Digarap\%20dari \%20Hulu\%20ke\%20Hilir.pdf

[2] Noor Eddy, "Analisa Struktur Chassis Kendaraan Serbaguna untuk Perkebunan," in Seminar Nasional Mesin dan Industri, Jakarta, 2009.

[3] Danardono Agus Sumarsono and Muhamad Agus Farhan, "Stress Analysis on Chassis Structure of hybrid Vehicle Using Finite Element Method," in 9th International Conference on Quality in Research, Depok, 2006.

[4] Roslan Abd Rahman, Mohd Nasir Tamin, and Ojo Kurdi, "Stress Analysis of Heavy Duty Truck Chassis as A Preliminary Data for Its Fatigue Life Prediction Using FEM," Jurnal Mekanikal, vol. 26, pp. 76-85, 2008.

[5] M.S.M Sani et al., "Stress Analysis and Modal Transient Response of Car Chassis," in International Conference on Advance Mechanical Engineering, Selangor, 2009.

[6] Patel Vijaykumar V and R.I. Patel, "Structural Analysis of Automotive Chassis Frame and Design Modification for Weight Reduction," International Journal of Engineering Research \& Technology, vol. 1, no. 3, 2012. 
[7] N.K. Ingole and D.V. Bhope, "Stress Analysis of Tractor Trailer Chassis for Self Weight Reduction," International Journal of Engineering Science and Technology, vol. 3, pp. 72187225, 2011.

[8] Didi Widya Utama and Roby Koeswojo, "Analisa Pengaruh Bentuk Profil Pada Rangka Kendaraan Ringan Dengan Metode Elemen Hingga," in Seminar Nasional Mesin dan Industri, Jakarta, 2012.

[9] William B. Riley and Albert R. George, "Design, Analysis, and Testing of A Formula SAE Car Chassis," in SAE Motorsports Engineering Conference and Exhibition, Indianapolis, 2002.

[10] Julian Happian Smith, Ed., An Introduction to Modern Vehicle Design. Oxford, UK: Butterworth-Heinemann, 2002 